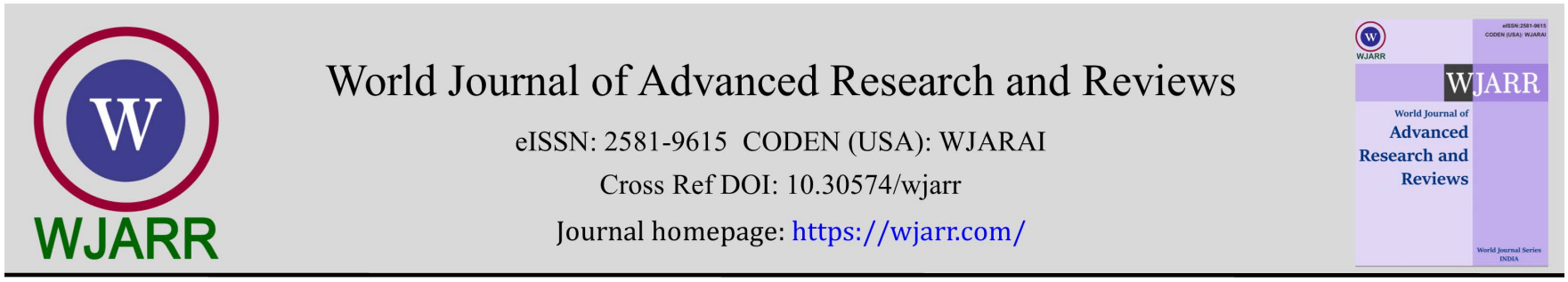

(RESEARCH ARTicle)

\title{
Production possibility of vetch and fodder pea in mixture with oats and the results of two-year macro experiment production in Tuzla canton area
}

\author{
Midhat Glavić ${ }^{1,}{ }^{*}$, Amir Zenunović ${ }^{1}$ and Robin Mujačić ${ }^{2}$ \\ ${ }^{1}$ Faculty of Technology, Department for Agriculture, University of Tuzla, Bosnia and Herzegovina. \\ 2 Independent consultants for Agriculture Tuzla, Bosnia and Herzegovina.
}

World Journal of Advanced Research and Reviews, 2022, 13(01), 631-637

Publication history: Received on 19 December 2021; revised on 22 January 2022; accepted on 24 January 2022

Article DOI: https://doi.org/10.30574/wjarr.2022.13.1.0081

\begin{abstract}
Agricultural lands for the production of forage crops in the area of Tuzla canton are limited. The settlement needs in the cattle feed of each area and climate zone used types and varieties that tolerate restrictions on land and climate. The settlement needs in the voluminous feed used types and varieties of forage crops in pure culture and in mixtures.

In our area are not sufficiently advanced species, and in particular mixtures of legumes (vetch and fodder peas) with grains the settlement needs in quality voluminous fodder (green, silage, hay), although there are very favorable conditions. For this purpose, to find existing and new production technologies that will be more rational, more acceptable and economically justifiable.

Aim of this study was to determine the yield of vetch and fodder pea with oats for use as silage in the macro experiment to determine optimum production technology for settlements the needs of the quality voluminous fodder for dairy farms.

Pilot production is set to two most significant localities for the production of milk in the Tuzla Canton, Gradacac and Tuzla.

Research was conducted through field trials in cooperation with agricultural farms engaged in milk production.

Field testing has found that the conditions of production with the use of appropriate cultural practices vetch and fodder peas mixed with oats satisfy the conditions of production and give very high yields of green mass of 29,12-36,87 tons per hectare.
\end{abstract}

Keywords: Vetch; Fodder pea; Yield; Protein; Cellulose

\section{Introduction}

Annual fodder legumes are suitable for cultivation in order to produce animal feed in different ways, thanks to their diversity, growth dynamics, maturing for use in a wide range of their adaptation to climate and soil. They can be grown for the production of grain, green fodder, hay, for silage and dehydration into flour [1].

\footnotetext{
${ }^{*}$ Corresponding author: Midhat Glavić

Faculty of Technology, Department for Agriculture, University of Tuzla, Bosnia and Herzegovina.

Copyright $(2022$ Author(s) retain the copyright of this article. This article is published under the terms of the Creative Commons Attribution Liscense 4.0.
} 
In the complex of intensifying livestock production, the solution should be sought in high-yielding crops, good quality, short vegetation, which fit into the system of continuous fodder production and meet the requirements of profitable forage crops [2].

Vetch (Vicia sativa L.) and fodder peas (Pisum sativum L.) are used in the form of green fodder, silage and hay. Due to the high-quality chemical composition of dry matter (high content of crude proteins and stimulating substances such as vitamin $\mathrm{C}$ ), they represent a very valuable component in the diet of all species and categories of domestic animals [3].

Highly productive dairy cows require adequate levels of energy, protein, vitamins, minerals and water in their diet, and the most important are proteins and energy due to their large share in the diet, and high production prices. Fodder legumes are one of the richest, but also potentially the cheapest sources of protein, and for profitable milk production, cows must consume large quantities of such high-quality fodder [4].

In the production of quality voluminous fodder to meet daily needs on green fodder and silage, very good results were achieved by combining fodder mixtures based on legumes and cereals, and alfalfa sown in monoculture [5].

In order to achieve the goal of producing quality fodder on one's own farm, it is necessary to determine: crops, cultivars and mixtures of crops; the most rational variants of production and use that will meet the needs of quantity and quality in a given period, sowing dates, use, ratios and fertilization, as well as how to store surplus produced fodder; technologies that will provide the necessary feed (shape and quantity) with the maximum possible protection of soil and environment in plant production systems. In our country, mixtures of legumes (peas, legumes) with cereals are not sufficiently expanded to meet the needs for quality forage (green, silage, hay) and grain (concentrate), although there are very favorable conditions for this [6].

Sowing legumes (fodder peas and vetch mixed with cereals and alfalfa) in fodder production can significantly reduce the need to add mineral fertilizers, especially nitrogen as the biggest pollutant of soil and water, with a strong environmental and finally economic impact that results in cheaper and more productive milk production [7].

Vetch and fodder peas are an excellent pre-crop for all cultivated plants except those from the legume family. Symbiosis with root nodule bacteria is the reason why it leaves large amounts of nitrogen in the soil in its harvest residues. After mowing beans and fodder peas, the land remains in a favorable structural condition and has enough time to perform all types of processing and preparation for sowing the next crop [8].

Sowing of vetch and fodder peas in a mixture with cereals provides better feed quality due to the high content of crude protein, due to the higher content of legumes in the mixture [9], increases biomass yield [10].

Growing legumes in a mixture with cereals reduces the use of non-renewable sources through reduced use of nitrogen (N) fertilizers, and also improves soil fertility [11].

Legumes after removal in the soil leave a few tons of easily degradable root mass and stubble per hectare which enriches the soil with organic matter, rich in nitrogen $(\mathrm{N})$. This expands the crop rotation, prevents the spread of certain diseases and pests, especially weeds, prevents soil fatigue, and most importantly allows continuous use of legumes in a mixture with cereals for feeding dairy cows in the form of green fodder, silage or as a concentrate (grain) [12].

The basic importance of growing annual fodder plants is reflected in: reduction of fertilization costs, preservation of moisture and prevention of nutrient leaching, repair of physical, chemical and biological properties of soil, prevention of erosion, reduction of pesticide use, preservation of water quality and preservation of environment and human health [13].

In our agro-ecological conditions, annual fodder legumes are often grown in the green fodder conveyor system, in the continuous system of green fodder production. In such a system of cultivation and utilization of fodder plants, an extremely good complete organization of the farm is necessary, especially the connection between plant and livestock production [14].

In addition to the production of quality fodder, winter crops are also used for green manure, especially in organic biological production of vegetables, because after their plowing the soil is introduced 100 to $200 \mathrm{~kg} /$ ha of nitrogen [15]. 
After plowing winter crops, the yield of the next crop increases, soil structure improves, soil organic matter increases, nutrient leaching is prevented, soil microbiological activity is improved, diseases, pests and weeds are controlled [16].

Also, in such mixtures weeds are less of a problem than in pure cereal crops, so protection from weeds is usually not needed, such combined crops do not require nitrogen fertilization for high feed yields, and the occurrence of diseases and pests is lower, which often eliminates the need for protection measures plants [17].

Despite the emphasized importance, both in terms of yield and quality, and in the system of protection of the agro ecological system, annual forage plants are grown in agro-ecological conditions of Tuzla Canton and the whole of Bosnia and Herzegovina on relatively small areas.

\section{Material and methods}

Field research was conducted during 2019, 2020 and 2021 in the area of the municipality of Gradacac, locality Turic, and in the area of the municipality of Tuzla, locality Gornja Tuzla. The following varieties were used in the research: winter fodder pea variety - Kosmaj, winter vetch- Neoplanta and winter oat variety Marta.

Quantity of seeds for sowing in mixtures is: fodder peas $120 \mathrm{~kg} / \mathrm{ha}$ plus winter oats $70 \mathrm{~kg} / \mathrm{ha}$, winter vetch $110 \mathrm{~kg} / \mathrm{ha}$ plus winter oats $70 \mathrm{~kg} / \mathrm{ha}$.

The pre-sowing of the first year of research on both plots was wheat, the second year due to the system of two harvests per year on the plots the pre-sowing was corn for silage. After mowing the mixture in 2020, corn for silage hybrid NS 4024 was sown. Agro technique of corn for silage: shallow plowing, basic fertilization 300 kg / ha NPK 15:15:15. Achieved yield of silage $38.7 \mathrm{t} / \mathrm{ha}$.

Experimental plots of 0.45 ha for the mixture of fodder peas and oats and 0.46 ha vetch and oats in the Gradacac, and 0.54 ha for the sowing of vetch and oats (Avena sativa L.) and 0.40 ha fodder pea and oats in the Tuzla.

Agro technique: plowing done on September 10, 2019. year and 13.09.2020. year. Sowing performed on October 1, 2019. year, 06.10.2020. year. Sowing was done with a grain drill at a distance of $12.5 \mathrm{~cm}$. In the basic cultivation in 2019 , $30 \mathrm{t}$ / ha of beef manure and NPK 10:30:20 300 kg / ha were plowed. In the fall of 2020, plowed NPK 10:30:20 300 kg / ha.

The chemical quality of green mass samples was determined by the following methods:

- $\quad$ proteins - (sample preparation, digestion, distillation, titration), Kjeldhal apparatus;

- $\quad$ moisture (dry matter) - automatic hygrometer (OHAUS);

- $\quad$ cellulose - manufacturer's method (VELP) - cellulose extractor;

\section{Results and discussion}

Table 1 Chemical characteristics of soils

\begin{tabular}{|l|c|c|c|c|}
\hline Locality & $\mathbf{p H}$ in $\mathbf{H}_{\mathbf{2}} \mathbf{O}$ & $\mathbf{N O}_{\mathbf{3}} \mathbf{\%}$ & $\mathbf{P}_{\mathbf{2}} \mathbf{O}_{\mathbf{5}} \mathbf{~ \mathbf { ~ g }} / \mathbf{1 0 0 g}$ & $\mathbf{K}_{\mathbf{2}} \mathbf{O} \mathbf{~ \mathbf { ~ g }} / \mathbf{1 0 0 g}$ \\
\hline Gradacac & 4.9 & 0.023 & 5 & 25 \\
\hline Tuzla & 4.9 & 0.032 & 8 & 16 \\
\hline
\end{tabular}

Table 2 The minimum, maximum and average of air temperatures $(\stackrel{\circ}{\circ} \mathrm{C})$ [18]

\begin{tabular}{|c|c|c|c|c|c|c|c|}
\hline \multicolumn{2}{|c|}{} & \multicolumn{3}{|c|}{ Gradacac } & \multicolumn{3}{c|}{ Tuzla } \\
\cline { 3 - 8 } \multicolumn{2}{|c|}{} & $\mathbf{2 0 1 9}$ & $\mathbf{2 0 2 0}$ & $\mathbf{2 0 2 1}$ & $\mathbf{2 0 1 9}$ & $\mathbf{2 0 2 0}$ & $\mathbf{2 0 2 1}$ \\
\hline \multirow{3}{*}{ Oct } & Min & 10.9 & 9.4 & & 6.6 & 6.6 & \\
\cline { 2 - 8 } & Max & 22.0 & 19.0 & & 22.7 & 19.1 & \\
\hline
\end{tabular}


World Journal of Advanced Research and Reviews, 2022, 13(01), 631-637

\begin{tabular}{|c|c|c|c|c|c|c|c|}
\hline & Average & 15.8 & 13.8 & & 13.0 & 11.7 & \\
\hline \multirow{4}{*}{ Nov } & Min & 7.2 & 4.0 & & 6.6 & 3.4 & \\
\cline { 2 - 8 } & Max & 15.3 & 9.0 & & 16.9 & 10.4 & \\
\cline { 2 - 8 } & Average & 10.9 & 6.3 & & 11.4 & 6.2 & \\
\hline \multirow{4}{*}{ Dec } & Min & 2.9 & 1.6 & & 0.1 & 1.6 & \\
\cline { 2 - 8 } & Max & 9.4 & 6.9 & & 9.2 & 8.4 & \\
\cline { 2 - 8 } & Average & 6.0 & 4.4 & & 4.2 & 4.8 & \\
\hline \multirow{4}{*}{ Jan } & Min & & -2.1 & -6.1 & & -3.6 & -9.1 \\
\cline { 2 - 8 } & Max & & 5.5 & 16.5 & & 7.0 & 16.4 \\
\cline { 2 - 8 } & Average & & 1.8 & 3.81 & & 0.9 & 2.41 \\
\hline Feb & Min & & 3.6 & -8.2 & & -0.1 & -11.4 \\
\cline { 2 - 8 } & Max & & 13.2 & 20.6 & & 12.8 & 22.5 \\
\hline & Average & & 8.0 & 6.99 & & 5.5 & 5.37 \\
\hline Mar & Min & & 4.2 & -3.1 & & 1.8 & -5.6 \\
\hline & Max & & 13.4 & 20.6 & & 13.3 & 20.5 \\
\hline & Average & & 8.4 & 6.91 & & 6.9 & 5.1 \\
\hline \multirow{5}{*}{ Apr } & Min & & 7.1 & -1.6 & & 3.7 & -3.9 \\
\hline & Max & & 20.3 & 26.2 & & 20.2 & 26.6 \\
\hline & Average & & 13.6 & 9.97 & & 12.0 & 8.66 \\
\hline May & Min & & 11.3 & 6.0 & & 8.4 & 1.5 \\
\hline & Max & & 20.9 & 29.8 & & 20.6 & 29.0 \\
\hline & Average & & 15.7 & 16.0 & & 14.1 & 14.7 \\
\hline & & & & & & & \\
\hline
\end{tabular}

Table 3 The monthly precipitations (mm) and number of day with rain and snow on the Gradacac area [18]

\begin{tabular}{|c|c|c|c|c|c|c|c|c|c|}
\hline \multirow[t]{4}{*}{ Month } & \multicolumn{9}{|c|}{ Gradacac } \\
\hline & \multicolumn{3}{|c|}{2019} & \multicolumn{3}{|c|}{2020} & \multicolumn{3}{|c|}{2021} \\
\hline & \multirow{2}{*}{$\frac{\text { Precipitation }}{\mathrm{mm}}$} & \multicolumn{2}{|c|}{ No. day } & \multirow{2}{*}{$\begin{array}{c}\text { Precipitation } \\
\mathrm{mm}\end{array}$} & \multicolumn{2}{|c|}{ No. day } & \multirow{2}{*}{$\frac{\text { Precipitation }}{\mathrm{mm}}$} & \multicolumn{2}{|c|}{ No. day } \\
\hline & & Rain & Snow & & Rain & Snow & & Rain & Snow \\
\hline Oct & 31.7 & 0 & 0 & 93.4 & 10 & 0 & & & \\
\hline Nov & 35.9 & 0 & 0 & 44.0 & 6 & 0 & & & \\
\hline Dec & 53.2 & 7 & 4 & 95.9 & 11 & 1 & & & \\
\hline Jan & & & & 33.7 & 5 & 4 & 124.4 & 16 & 14 \\
\hline Feb & & & & 60.2 & 5 & 1 & 35.5 & 7 & 13 \\
\hline Mar & & & & 55.1 & 7 & 5 & 46.1 & 10 & 0 \\
\hline Apr & & & & 24.5 & 4 & 1 & 57.4 & 17 & 1 \\
\hline May & & & & 129.1 & 18 & 0 & 89.6 & 15 & 0 \\
\hline
\end{tabular}


Table 4 The monthly precipitations (mm) and number of day with rain and snow on the Tuzla area [18]

\begin{tabular}{|c|c|c|c|c|c|c|c|c|c|}
\hline \multirow[t]{4}{*}{ Month } & \multicolumn{9}{|c|}{ Tuzla } \\
\hline & \multicolumn{3}{|c|}{2019} & \multicolumn{3}{|c|}{2020} & \multicolumn{3}{|c|}{2021} \\
\hline & \multirow{2}{*}{$\begin{array}{c}\text { Precipitation } \\
\mathbf{m m}\end{array}$} & \multicolumn{2}{|c|}{ No. day } & \multirow{2}{*}{$\begin{array}{c}\text { Precipitation } \\
\mathrm{mm}\end{array}$} & \multicolumn{2}{|c|}{ No. day } & \multirow{2}{*}{$\begin{array}{c}\text { Precipitation } \\
\mathrm{mm}\end{array}$} & \multicolumn{2}{|c|}{ No. day } \\
\hline & & Rain & Snow & & Rain & Snow & & Rain & Snow \\
\hline Oct & 37.7 & 7 & 0 & 79.8 & 12 & 0 & & & \\
\hline Nov & 57.9 & 16 & 0 & 29.8 & 15 & 0 & & & \\
\hline Dec & 87.3 & 11 & 7 & 70.8 & 15 & 1 & & & \\
\hline Jan & & & & 35.7 & 6 & 3 & 160.1 & 21 & 16 \\
\hline Feb & & & & 67.1 & 8 & 5 & 34.8 & 8 & 1 \\
\hline Mar & & & & 39.5 & 7 & 4 & 78.5 & 13 & 4 \\
\hline Apr & & & & 23.4 & 7 & 1 & 59.3 & 16 & 1 \\
\hline May & & & & 112.1 & 18 & 0 & 86.7 & 15 & 0 \\
\hline
\end{tabular}

Table 5 Harvest time of fodder crop mixtures

\begin{tabular}{|l|l|l|}
\hline $\begin{array}{c}\text { Developmental stages of } \\
\text { mixtures by mowing dates }\end{array}$ & \multicolumn{1}{|c|}{ 18. may. 2020. year } & \multicolumn{1}{c|}{ 24.may. 2021. year } \\
\hline Oat & Beginning of milk ripening of grains & Beginning of milk ripening of grains \\
\hline Fodder pea & The beginning of the formation of pods & The beginning of the formation of pods \\
\hline Vetch & The beginning of the formation of pods & The beginning of the formation of pods \\
\hline
\end{tabular}

Table 6 Yields of green mass t/ha

\begin{tabular}{|l|c|c|c|c|}
\hline \multirow{2}{*}{ Mixture } & \multicolumn{2}{c|}{ Gradacac } & \multicolumn{2}{c|}{ Tuzla } \\
\cline { 2 - 5 } & 2020. & 2021. & 2020. & 2021. \\
\hline Fodder pea + oat & 34.93 & 31.19 & 36.87 & 34.35 \\
\hline Vetch + oat & 31.28 & 29.12 & 32.32 & 30.18 \\
\hline
\end{tabular}

[19] Yields of green fodder beans mixed with cereals in our country are:

- $\quad$ Common vetch - 25-40 t/ha,

- Winter hairy vetch - 35-45 t/ha and

- Pannonia vetch - 25-45 t / ha.

[19] Yields of green pea fodder in a mixture with cereals are 30-50 $t$ / ha, and hay of 7-12 $t$ / ha. The yield of fodder pea sown in pure sowing is lower and ranges from 20-30 $t$ / ha, and hay 6-9 $t$ / ha.

The yields achieved in this macro experiment are in line with the yields of previous research. 
Table 7 The share of legumes and oats in the yield of green mass (\%)

\begin{tabular}{|l|c|c|c|c|c|c|}
\hline \multirow{2}{*}{ Locality } & \multicolumn{2}{|c|}{ Fodder pea } & \multicolumn{2}{c|}{ Vetch } & \multicolumn{2}{c|}{ Oat } \\
\cline { 2 - 7 } & 2020. & 2021. & 2020. & 2021. & 2020. & 2021 \\
\hline Gradacac & 61.3 & 63.3 & 64.5 & 65.8 & 38.7 & 36.7 \\
\hline Tuzla & 58.1 & 65.4 & 61.7 & 61.2 & 41.9 & 34.6 \\
\hline
\end{tabular}

The results of the research are in line with previous research in other areas.

[20] States that in Slovenia the share of legumes in the yield of green mass from $51,0 \%$ to $81,64 \%$, and the share of oats in the amount of $17,0 \%$ from $59,3 \%$.

Table 8 Dry matter content in fodder mixtures (\%)

\begin{tabular}{|l|c|c|c|c|}
\hline \multirow{2}{*}{\multicolumn{1}{|c|}{ Mixture }} & \multicolumn{2}{c|}{ Gradacac } & \multicolumn{2}{c|}{ Tuzla } \\
\cline { 2 - 5 } & 2020. & 2021. & 2020. & 2021. \\
\hline Fodder pea + oat & 35.1 & 34.5 & 36.7 & 34.5 \\
\hline Vetch + oat & 33.2 & 32.3 & 32.5 & 31.7 \\
\hline
\end{tabular}

[21] State values of 15 to $30 \%$ ST in green mass in the phases from wilting to earlier.

The research has slightly higher dry matter content due to later mowing.

Table 9 Average content of crude proteins in the dry matter of fodder mixtures (\%)

\begin{tabular}{|l|c|c|c|c|}
\hline \multirow{2}{*}{\multicolumn{1}{|c|}{ Mixture }} & \multicolumn{2}{c|}{ Gradacac } & \multicolumn{2}{c|}{ Tuzla } \\
\cline { 2 - 5 } & 2020. & 2021. & 2020. & 2021. \\
\hline Fodder pea + oat & 13.59 & 12.38 & 14.50 & 13.60 \\
\hline Vetch + oat & 13.08 & 11.90 & 12.10 & 12.09 \\
\hline
\end{tabular}

\section{Conclusion}

Fodder peas and green beans are two legumes that, in combination with small grains, have great potential in providing quality bulky food on farms in the Tuzla Canton.

Achieved green mass yields are an indicator of appropriate climatic and soil conditions in the production of these crops. The applied agro technique is an indicator that with the observance of agro technical measures, good yields of green mass of vetch and fodder peas in combination with cereals can be achieved.

In addition to these mentioned advantages, vetch and fodder peas are crops that enable a system of two harvests a year, which all depends on the weather conditions. After the harvest of vetch and fodder peas, it is possible to sow corn for silage, earlier groups of ripening.

The quality of voluminous feed, green mass or legume and pea silage has already been proven in terms of protein content, the mowing time is significant. Also, the quality of hay is much better than hay from meadows and pastures.

\section{Compliance with ethical standards}

\section{Acknowledgments}

Only published papers that have been cited have been used, and are listed in the references. 


\section{Disclosure of conflict of interest}

There is no conflict of interest. The results were obtained by our own survey and questionnaires -Midhat Glavić and other coauthors.

\section{References}

[1] Mišković B. Forage crops, Science book, Belgrade. 1986.

[2] Ćupina B, Mihailović V, Erić P. Effect of growth stage and geno type on protein content and distribution in fodder pea. VII ESA Congress, Cordoba, Spain. 2002; 435-436.

[3] Mišković B. Forage crops, Science book, Beograd. 1986.

[4] Maćešić D. Organic breeding of fodder crops for dairy cows, Faculty of Agriculture, University Zagreb. 2010.

[5] Maćešić D. Organic breeding of fodder crops for dairy cows, Faculty of Agriculture, University Zagreb.2010

[6] Štafa Z. New technologies in the production of peas and legumes for livestock, Faculty of Agriculture, University of Zagreb. 2007.

[7] Maćešić D. Organic breeding of fodder crops for dairy cows, Faculty of Agriculture, University Zagreb. 2010.

[8] Ocokoljić S. Leguminous plants in livestock nutrition, Science book, Belgrade.1974.

[9] Umuna NN, Osuji PO, Nsahlai IV. Strategic supplementation of crossbred steers fed forages from cereal legume cropping systems with cow pea hay. Journal of Applied Animal Research. 1997; 11: 169-182.

[10] Lithourgidis AS, Vasilakoglou IB, Dhima KV, Dordas CA, Yiakoulaki MD. Forage yield and quality of common vetch mixtures with oat and triticale in two seedling ratios. Field Crops Research. 2006; 99: 106-113.

[11] Banik P, Bagchi DK. Effect of legumes as a sole and intercrop on residual soil fertility and succeeding crop in upland situation. Indian Journal of Agricultural Sciences. 1993; 37: 69-75.

[12] Russel JE. Soil conditions and Plant growth. Hongmais Green and Co., London, New York, Toronto. 1950.

[13] Ćupina B, Erić P, Mihailović V, Mikic A, Krstic Dj, Vuckovic S. Significance, condition and perspectives of annual fodder plants in agro-ecological conditions of Serbia, Institute of Field and Vegetable Crops, Novi Sad. 2007.

[14] Ćupina B, Erić P, Mihailović V, Mikic A, Krstic Dj, Vuckovic S. Significance, condition and perspectives of annual fodder plants in agro-ecological conditions of Serbia, Institute of Field and Vegetable Crops, Novi Sad. 2007.

[15] Mihalić V. General production of plants. School book. Zagreb. 1976.

[16] Eberhard S. The meaning of intercropping, Zagreb. 1975.

[17] Baranj I. Cereals in the production of forage. Graduate work. J. J. Strossmayer University of Osijek, Faculty of Agriculture. Osijek.

[18] Federal Hydro meteorological Institute, Federation Bosnia and Herzegovina, Meteorological Yearbook: 2019, 2020, 2021

[19] Gatarić DJ, Drinić M, Radić V, Kralj A. Production on arable land and nutritional value forage plants, East Sarajevo. 2015.

[20] Kostelic K. Yield and Quality of some Fodder Catch Crops in Dolenjska. AGRICULTURAE CONSPECTUS SCIENTIFICUS, Croatia. 1998; 63: 1-14.

[21] Štafa Z, Stjepanović M. Winter and optional fodder crops. Croatian Dairy Association. 2015. 